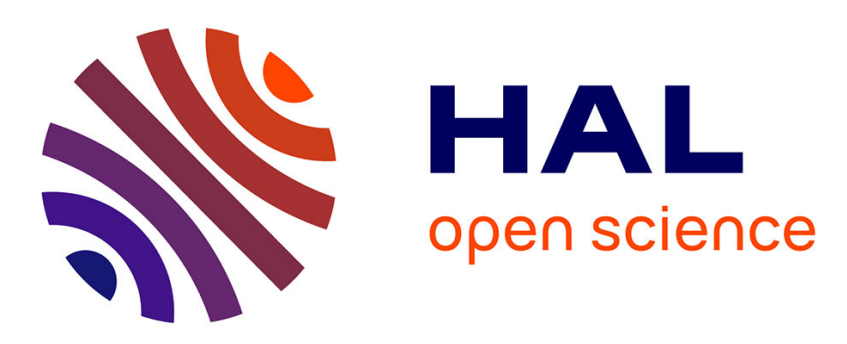

\title{
Rotating disk electrodes to assess river biofilm thickness and elasticity
}

Stéphanie Boulêtreau, Jean-Yves Charcosset, Jean Gamby, Emilie Lyautey, Sylvain Mastrorillo, Frédéric Azémar, Frédéric Moulin, Bernard Tribollet, Frédéric Garabetian

\section{To cite this version:}

Stéphanie Boulêtreau, Jean-Yves Charcosset, Jean Gamby, Emilie Lyautey, Sylvain Mastrorillo, et al.. Rotating disk electrodes to assess river biofilm thickness and elasticity. Water Research, 2011, 45 (3), pp.1347-1357. 10.1016/j.watres.2010.10.016 . hal-00809102

\section{HAL Id: hal-00809102 https: / hal.sorbonne-universite.fr/hal-00809102}

Submitted on 26 Jan 2022

HAL is a multi-disciplinary open access archive for the deposit and dissemination of scientific research documents, whether they are published or not. The documents may come from teaching and research institutions in France or abroad, or from public or private research centers.
L'archive ouverte pluridisciplinaire HAL, est destinée au dépôt et à la diffusion de documents scientifiques de niveau recherche, publiés ou non, émanant des établissements d'enseignement et de recherche français ou étrangers, des laboratoires publics ou privés. 


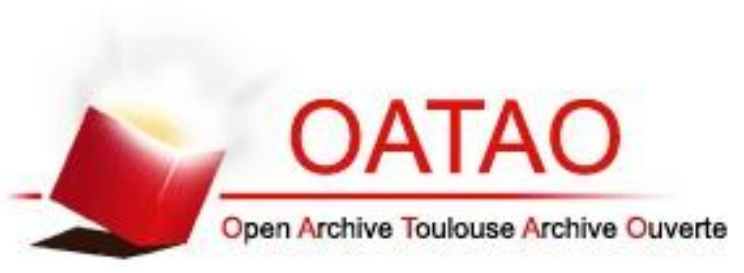

Open Archive Toulouse Archive Ouverte (OATAO)

OATAO is an open access repository that collects the work of Toulouse researchers and makes it freely available over the web where possible.

This is an author-deposited version published in: http://oatao.univ-toulouse.fr/ Eprints ID: 4573

To link to this article: DOI: $10.1016 /$ j.watres.2010.10.016 http://dx.doi.org/10.1016/j.watres.2010.10.016

\section{To cite this version:}

Boulêtreau, Stéphanie and Charcosset, Jean-Yves and Gamby, Jean and Lyautey, Emilie and Mastrorillo, Sylvain and Azémar, Frédéric and Moulin, Frédéric and Tribollet, Bernard and Garabétian, Frédéric (2011) Rotating disk electrodes to assess river biofilm thickness and elasticity. Water Research, vol. 45 ( $\left.{ }^{\circ} 3\right)$. pp. 1347-1357. ISSN 0043-1354

Any correspondence concerning this service should be sent to the repository administrator: staff-oatao@inp-toulouse.fr 


\title{
Rotating disk electrodes to assess river biofilm thickness and elasticity
}

\author{
Stéphanie Boulêtreau ${ }^{a, b, *}$, Jean-Yves Charcosset ${ }^{a, b}$, Jean Gamby ${ }^{d}$, Emilie Lyautey ${ }^{a, b}$, \\ Sylvain Mastrorillo ${ }^{a, b}$, Frédéric Azémar $^{a, b}$, Frédéric Moulin $^{c}$, Bernard Tribollet ${ }^{d}$, \\ Frédéric Garabetian ${ }^{e}$ \\ ${ }^{a}$ Université de Toulouse, UPS, INP, EcoLab (Laboratoire d'écologie fonctionnelle), 118 route de Narbonne, F-31062 Toulouse, France \\ ${ }^{\mathrm{b}}$ CNRS, EcoLab, F-31062 Toulouse, France \\ ${ }^{c}$ Institut de Mécanique des Fluides de Toulouse, UMR 5502, Allée du Professeur Camille Soula, 31400 Toulouse, France \\ ${ }^{\mathrm{d}}$ Laboratoire Interfaces et Systèmes Electrochimiques LISE, UPR 15 du CNRS, Université Pierre et Marie Curie, 4 place Jussieu, \\ 75252 Paris cedex 05, France \\ ' Université de Bordeaux, EPOC-OASU, UMR 5805, Station Marine d'Arcachon, 2 rue du Professeur Jolyet, 33120 Arcachon, France
}

Keywords:

Epilithon

Periphyton

Biofilm architecture

Biofilm deformation

Voltammetry

Electrochemistry
A B S T R A C T

The present study examined the relevance of an electrochemical method based on a rotating disk electrode (RDE) to assess river biofilm thickness and elasticity. An in situ colonisation experiment in the River Garonne (France) in August 2009 sought to obtain natural river biofilms exhibiting differentiated architecture. A constricted pipe providing two contrasted flow conditions (about 0.1 and $0.45 \mathrm{~m} \mathrm{~s}^{-1}$ in inflow and constricted sections respectively) and containing $24 \mathrm{RDE}$ was immersed in the river for 21 days. Biofilm thickness and elasticity were quantified using an electrochemical assay on 7 and 21 days old RDE-grown biofilms ( $t_{7}$ and $t_{21}$, respectively). Biofilm thickness was affected by colonisation length and flow conditions and ranged from $36 \pm 15 \mu \mathrm{m}$ (mean \pm standard deviation, $n=6$ ) in the fast flow section at $t_{7}$ to $340 \pm 140 \mu \mathrm{m}(n=3)$ in the slow flow section at $t_{21}$. Comparing the electrochemical signal to stereomicroscopic estimates of biofilms thickness indicated that the method consistently allowed (i) to detect early biofilm colonisation in the river and (ii) to measure biofilm thickness of up to a few hundred $\mu \mathrm{m}$. Biofilm elasticity, i.e. biofilm squeeze by hydrodynamic constraint, was significantly higher in the slow $\left(1300 \pm 480 \mu \mathrm{m} \mathrm{rpm}^{1 / 2}\right.$, $n=8)$ than in the fast flow sections $\left(790 \pm 350 \mu \mathrm{m} \mathrm{rpm}{ }^{1 / 2}, n=11\right)$. Diatom and bacterial density, and biofilm-covered RDE surface analyses (i) confirmed that microbial accrual resulted in biofilm formation on the RDE surface, and (ii) indicated that thickness and elasticity represent useful integrative parameters of biofilm architecture that could be measured on natural river assemblages using the proposed electrochemical method.

\section{Introduction}

River epilithic biofilms are complex microbial consortia of algae, bacteria and other micro- and meso-organisms that develop on solid substrata (Lock, 1993). Embedded in a mucilage matrix of microbially generated biopolymers (EPS: extracellular polymeric substances), these aggregates have relatively high mechanical stability and cell density. River biofilm dynamics influences

\footnotetext{
* Corresponding author. Tel.: +33 (0) 5615573 48; fax: +33 (0) 561556096 .

E-mail address: stephanie.bouletreau@cict.fr (S. Boulêtreau).

0043-1354/\$ - see front matter @ 2010 Elsevier Ltd. All rights reserved.

doi:10.1016/j.watres.2010.10.016
} 
various instream processes such as primary production (Wetzel, 1975), river food web (Feminella and Hawkins, 1995), organic matter and nutrient cycling (Paul et al., 1991; Battin et al., 2003a; Teissier et al., 2007), and accumulation of contaminants such as pesticides (Dorigo et al., 2007) and toxic metals (Cheng et al., 2008; Thuy Dong et al., 2008).

Biofilm architecture (e.g. thickness, cohesion) varies with community maturation and resistance to current velocity, both for monospecific biofilms (e.g. Mukherjee et al., 2008) or for complex river biofilms (Peterson, 1996). Architecture partly conditions biofilm functions affecting mass transfer between aggregates and bulk water, influencing for example the relative uptake of substrates differing in bioavailability (Battin et al., 2003b). In spite of its major interest, the in situ characterisation of biofilm architecture remains a challenge since tools are very scarce, inconvenient to use in the field and somewhat semiquantitative. Among architectural parameters, thickness is the most integrative and informative with respect to variation in key parameters including volume, wet weight, and number of species. However river biofilm thickness is rarely measured and studies often intentionally use biomass as an indirect estimation of thickness (Dodds et al., 1999). Several destructive (scanning electron microscopy, cryoembedding) and nondestructive (light microscopy, scanner with an image acquisition system, a laser triangulation sensor, confocal laserscanning microscopy and two-photon excitation microscopy) optical methods are available to measure biofilm thickness (Paramonova et al., 2007). They are ideal tools for biofilm monitoring at the micrometer scale spatial resolution. Investigations on bacterial biofilms are also oriented towards nanoscopic spatial arrangement using a combination of confocal laser-scanning microscopy and atomic force microscopy (Schmid et al., 2008). The main drawback for their application to river biofilm is the incompatibility between their observation scale and the centimetre or metre scale of biofilm development in rivers (e.g. on rock substrates such as pebbles). An optical method (Bakke and Olsson, 1986), periodically applied for river and estuarine biofilms (Sekar et al., 2002; Rao, 2003) determines biofilm thickness as the vertical sample displacement required to move the focal plane of the microscope from the water-biofilm interface to the biofilm-substratum interface. It is limited in that an estimate of the refractive index of the transparent film is required and it can only be applied to biofilm thinner than $100 \mu \mathrm{m}$ (Paramonova et al., 2007).

Herbert-Guillou et al. (1999) reported an electrochemical method based on the analysis of a tracer oxidation current on a rotating disk electrode (RDE) where biofilm has developed. This electrochemical technique was applied to detect very thin bacterial biofilms developed in sea and tap waters (Herbert-Guillou et al., 2000; Gamby et al., 2008). Beside thickness measurement, Herbert-Guillou et al. (2000) showed that the RDE method could be used to provide complementary information on biofilm functional properties relative to biofilm elasticity.

The objectives of the present study were to (i) adapt the RDE method to estimate natural phototrophic biofilm thickness and elasticity and particularly, (ii) improve the biofilm elasticity parameter calculation, (iii) assess the relevance of thickness and biofilm elasticity measurements to differentiate contrasted river phototrophic biofilms and, (iv) prove the suitability of this method for in situ experiments. As flow rate and biofilm maturation are proved to influence biofilm architecture (Peterson, 1996), we designed an experimental device to produce 7-day and 21-day-old biofilms in situ while varying the flow rate.

\section{Materials and methods}

\subsection{Experimental design}

\subsubsection{Biofilm production device}

An experimental pipe device for biofilm production was designed and scaled to provide two contrasted current velocity conditions within the same pipe, so that all factors affecting biofilm dynamics other than flow could be considered similar. According to the volume continuity equation for an incompressible fluid, through a pipe constriction (from the section \#1 of area $A_{1}$ to the section \#2 of area $A_{2}$ ), (i) the fluid velocity increases and (ii) this increase in velocity (from $v_{1}$ to $v_{2}$ ) is set to the decrease in section area as follows: $v_{2} / v_{1}=A_{1} / A_{2}$.

The constricted pipe consisted in three main parts: an upstream first cylinder (section \#1, slow flow) followed by a converging conical inlet (angle $\alpha_{1}$ ) and a second downstream cylindrical throat (section \#2, fast flow) (Fig. 1.). The current velocity $v_{1}$ was determined by the local river current velocity and followed river flow variations during the whole experiment. The current velocity $v_{2}$ depends on $v_{1}$ value and on the ratio between diameters $\left(\Phi_{2} / \Phi_{1}\right)$. Diameter dimensions were chosen (i) to provide a quite easily handling structure, (ii) to ensure relatively homogeneous flow conditions in each section and (iii) to ensure a ratio $v_{2} / v_{1}$ around 4 . Inlet and throat diameters were set to 20 and $10 \mathrm{~cm}$ respectively. A diverging recovery part (angle $\alpha_{2}$ ) followed by a third cylindrical throat (section \#3; diameter $\Phi_{3}=\Phi_{1}$ ) was added to the structure to ensure a straight exit stream. Convergence and divergence angles were chosen according to values minimising flow detachment and head loss in Venturi pipes: $\alpha_{1}=20^{\circ}$ and $\alpha_{2}=14^{\circ}$. Numerous formulas are found to estimate the entrance length $\left(l_{e}\right)$ of cylindrical ducts i.e. the position beyond which flow is fully developed (Anselmet et al., 2009). Application of such formulas to the present flow conditions yields values of $l_{e} / \Phi_{e}$ between 20 and 30 lead to too long pipe dimensions to be handled in the river. Entry and constricted section lengths were set to 3 and 4 times the diameter, the total length being therefore $186 \mathrm{~cm}$. At RDE locations, viscous shear stress on the cylinder (and incidentally on biofilm) is around 10 times larger in the constricted than in the entry section, ensuring relative homogeneous and contrasted local flows at RDE surfaces.

The constricted pipe was made of 3-mm thick Plexiglas ${ }^{\circledR}$ to ensure light diffusion. Pipe sections for which diameter was smaller than $\Phi_{1}$ were surrounded with another 20-cm diameter Plexiglas ${ }^{\circledR}$ pipe to form a single continuous pipe and decrease detachment of the external flow around the pipe. The additional sheath did not affect light penetration: irradiance in both sections of the pipe, as measured using a LI-COR Li100 quantameter at sunlight, exhibited similar values within a 10\% range.

\subsubsection{Experimental procedure}

Twelve RDE were incorporated at each downstream extremity of both sections of the apparatus (Fig. 1). The RDE were labelled 


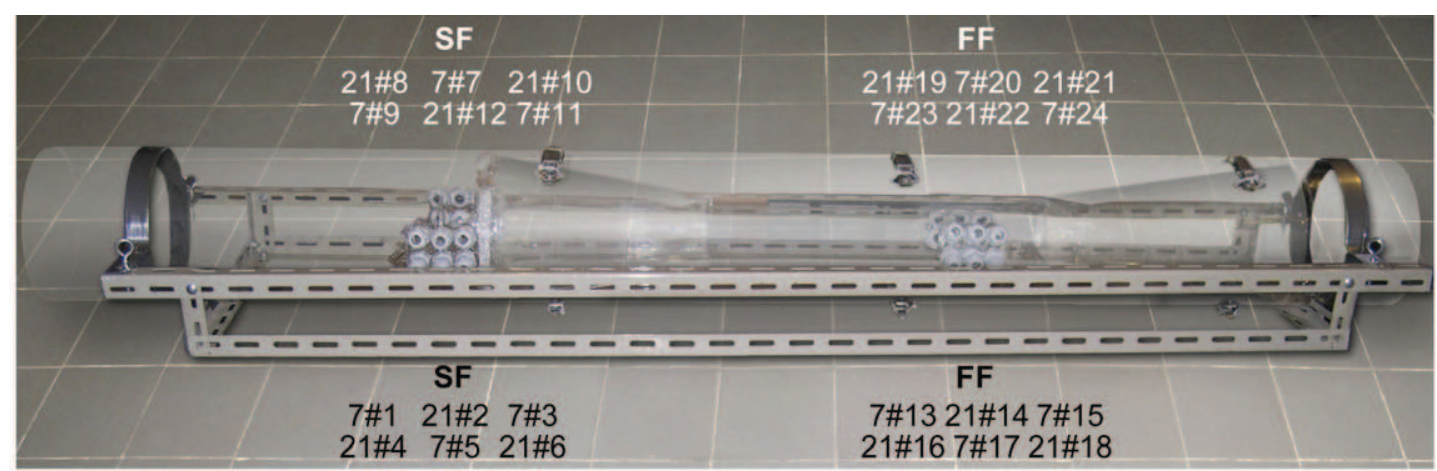

$186 \mathrm{~cm}$

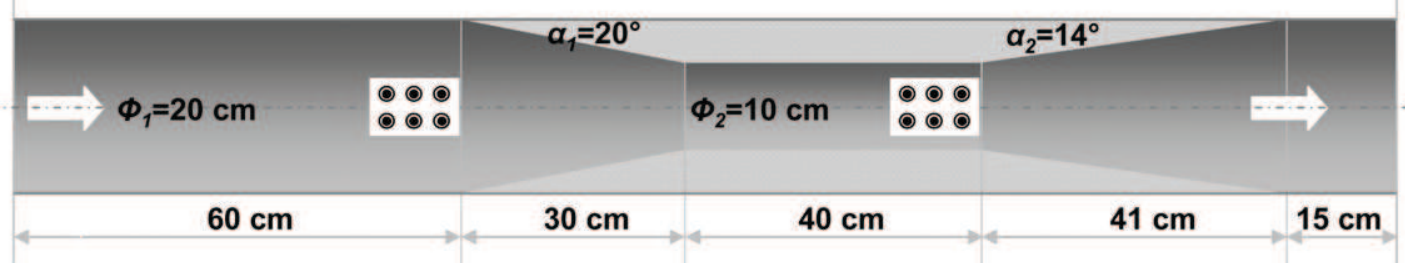

Fig. 1 - Photograph and schematic representation of the experimental pipe device. The position of the RDEs is indicated on the photograph by its labelling. SF: slow flow section; FF: fast flow section; 7: 7 days; $21: 21$ days. Arrow shows current direction.

SF (for slow flow) or FF (for fast flow) according to which section they were located. In each section, the surface of $6 \mathrm{RDE}$ per pipe side (right and left) was vertically positioned at the equator line to prevent particle sedimentation during the colonisation process. The RDE were positioned next to each other to ensure homogeneous environmental conditions between replicates. They were maintained in order to arise to the pipe internal surface with nylon cable gland allowing an easy recovery.

The constricted pipe was immersed parallel to the water current at the bottom of the River Garonne at the study site of $l^{\prime}$ Aouach $\left(01^{\circ} 18^{\prime} 00^{\prime \prime} \mathrm{E} ; 43^{\circ} 23^{\prime} 08^{\prime \prime} \mathrm{N}\right)$. This site is a typical reach for biofilm development (Lyautey et al., 2005; Boulêtreau et al., 2006). During the low-water period (from July to October), the study river reach is characterised by a shallow $(<1.5 \mathrm{~m})$, wide $(100 \mathrm{~m})$, and unshaded bed. Water exhibits low turbidity $(<30$ NTU) and nutrient concentrations of about $10 \mu \mathrm{P} \mathrm{L} \mathrm{L}^{-1}$ of soluble reactive phosphorus, $1 \mathrm{mg} \mathrm{N} \mathrm{L}^{-1}$ of both ammonium and nitrates, and $1.5 \mathrm{mg} \mathrm{C} \mathrm{L}^{-1}$ of dissolved organic carbon. The constricted pipe was maintained on the river bottom in a zone where the riverbed was flat and homogeneous (boulder rocks), shallow (water depth around $50 \mathrm{~cm}$ ) and current velocity was slow (around $0.1 \mathrm{~m} \mathrm{~s}^{-1}$ ). The experiment was performed on August 2009 during a low-flow period to exploit the most stable current velocities as possible, and to enable biofilm accrual especially in the fast flow section. Data on daily mean flow were supplied by DIREN Midi-Pyrénées (gauging station: Portet-sur-Garonne) and mean current velocity was measured at the pipe entry using an FLO-MATE portable flowmeter (Model 2000, Marsh-McBirney, USA).

The device was immersed for 21 days, and six RDE per section were sampled after $7\left(t_{7}\right)$ and $21\left(t_{21}\right)$ days of colonisation. Replicate RDE were named as follows: SF or FF when collected in the slow flow or fast flow section followed by 7 or 21 according to the sampling time, and followed by the replicate number; RDE SF7\#3 stands for one of the RDE sampled in the slow flow section after 7 days of colonisation. Sampled $\mathrm{RDE}$ were kept in river water at $4{ }^{\circ} \mathrm{C}$ in the dark during transport to the laboratory and measurements were performed within $5 \mathrm{~h}$. At $\mathrm{t}_{7}$ the 12 sampled RDE were replaced by stainless-steel cylinders of similar diameter.

\subsection{Biofilm architecture measurements}

\subsubsection{Electrochemical measurement theory}

The method consists of measuring the steady-state diffusion current on the RDE interface at a fixed potential and at a fixed rotation speed $\Omega$ without biofilm ( $\mathrm{t}_{0}$ ) and after biofilm development ( $t_{7}$ and $t_{21}$ ). To impose this constant potential, a 3electrode-system immersed in an electrochemical cell filled with a tracer solution and connected to a potentiostat was used: (i) RDE, the working metallic electrode on which biofilm develops; (ii) the reference electrode that controls the potential of the working electrode and (iii) the counter electrode that closes the electrical circuit and the overall current goes through. Diffusion current results in the oxidation of a reduced species at the RDE-electrolyte interface. Without biofilm, diffusion current depends directly on the diffusion boundary layer thickness at the RDE-electrolyte interface. With $\mathrm{RDE}$ rotating at a constant rotation speed around its axis, the diffusion boundary layer thickness is maintained constant. Biofilm is considered as an inert porous layer with respect to mass transport since it contains more than $95 \%$ of water (Characklis, 1990). The biofilm is also considered as a layer of stagnant water on the RDE surface, and the slow convection 
existing inside the biofilm is neglected. The diffusion coefficient in biofilm was shown to be the same as the diffusion coefficient in water (L'Hostis et al., 1996), this property is extended for the thicker river biofilms under investigation in the present study. This layer adds to the hydrodynamic boundary layer one, inducing a decrease in diffusion current intensity.

\subsubsection{Electrochemical measurement setting}

The RDE was made of a $5-\mathrm{mm}$ diameter platinum cylinder (electrical conductor) coated with a Teflon ${ }^{\circledR}$ cylinder (electrical insulator). The reference electrode was a saturated calomel electrode (SCE) (REF421, Radiometer Analytical, France). The counter electrode was a cylindrical grid of platinum immersed into the electrolyte solution that surrounded the working electrode. A $0.01 \mathrm{M}$ potassium ferrocyanide $\left[\mathrm{Fe}(\mathrm{CN})_{6}\right]^{2-}$ and ferricyanide $\left[\mathrm{Fe}(\mathrm{CN})_{6}\right]^{3-}$ solution was used as tracer in $1 \mathrm{M} \mathrm{KCl}$. Ferrocyanide oxidation current intensity was measured at $0 \mathrm{~V} /$ SCE at which no water electrolysis and no oxygen reduction occur. Measurements were performed at $20^{\circ} \mathrm{C}$.

In the laboratory, the RDE was mounted on a motor axis plugged using mercury contacts and was rotated by a DC motor system. The motor speed was controlled with a servo system and measured using a tachometer. Prior to diffusion current measurements, the equilibrium potential of the ferrocynanide/ ferricyanide couple at the same concentration was measured between -0.240 and $-0.236 \mathrm{~V} / \mathrm{SCE}$ in accordance with the reference potential $(-0.237 \mathrm{~V} / \mathrm{SCE})$. Diffusion current was then measured at the potential $0 \mathrm{~V} / \mathrm{SCE}$ for each RDE rotation speed between 100 and $1200 \mathrm{rpm}$ by steps of $100 \mathrm{rpm}$. Rotation speed was limited to $1200 \mathrm{rpm}$ to prevent biofilm erosion. Before $t_{0}$ measurements, every RDE were polished using sandpaper (grade 1200) and cleaned with distilled water. After $t_{7}$ and $t_{21}$ measurements, each RDE was individually conditioned into river water until further analyses.

Biofilm thickness $\delta(\mu \mathrm{m})$ was calculated from diffusion current intensity measurements with $(i(t))$ and without biofilm (i(0)) for each RDE rotation speed ( $\Omega$ in rpm) as follows:

$\delta=n F D C^{*} S\left[i(t)^{-1}-i(0)^{-1}\right] \times 10,000$

with $n$ is the number of electrons, $F$ the Faraday constant ( $96485 \mathrm{C} \mathrm{mol}^{-1}$ or s A mol${ }^{-1}$ ), $D$ the diffusion coefficient in both water and biofilm set to $6.8 \times 10^{-6} \mathrm{~cm}^{2} \mathrm{~s}^{-1}$ at $20^{\circ} \mathrm{C}$ according to Deslouis et al. (1980), $C^{*}$ the electroactive species concentration in the bulk solution $\left(0.00001 \mathrm{~mol} \mathrm{~cm}^{-3}\right)$, and $\mathrm{S}$ the active RDE area $\left(0.196 \mathrm{~cm}^{2}\right)$.

\subsubsection{Image acquisition and analysis}

For RDE biofilm cover estimations, stereomicroscopy (Olympus SZX10, 24× magnification) images of the bare RDE ( $\left.t_{0}\right)$ and the wet colonised $\mathrm{RDE}\left(\mathrm{t}_{7}\right.$ or $\left.\mathrm{t}_{21}\right)$ surfaces were captured using an Olympus U-TV0.63XC camera (Olympus Corporation, Tokyo, Japan) as TIFF files (1600 by 1200 pixels) and imported in Photoshop CS3 (Adobe Photoshop v 10.0.1). No staining was performed. The image of the bare RDE surface was used as control. Binary images were generated by affecting the white color to the bare pixels and the black color to the colonised pixels. RDE biofilm cover (surface \%) was determined on the platinum surface as the ratio of the surface area of black pixels to the total surface area (sum of white and black pixels) with Image J 1.37v (Wayne Rasband, National Institutes of Health, USA).

For thickness estimation, stereomicroscopy (Leica MZ 12.5, $16 \times$ magnification) images of a side view of each colonised RDE standing in water were captured using a Leica DFC320 camera (Leica Microsystems DI Cambridge). Several focal planes corresponding to various cross sections $((x, z)$-planes in a $(x, y, z)$ coordinate system) were visible on the picture thanks to the setting of an appropriate depth of field. The projected image of the various focal planes was converted to binary image after biofilm pixels selection. The maximal biofilm height (maximal $z$-coordinate of the (y, z)-plane) on each abscissa of the image ( $x$-axis) was measured automatically in pixels using Image J. Conversion from pixel to $\mu \mathrm{m}$ was performed using a line scale standard. This gives the mean maximal biofilm thickness (mean $z_{\max }$ ) of the whole colonised RDE surface (( $\left.x, y\right)$-plane).

\subsubsection{Cell numeration}

After electrochemical measurements, material on the RDE surface was removed with a sterile scalpel and placed into $1 \mathrm{~mL}$ of filter-sterilized $(0.2 \mu \mathrm{m}$ pore-size filter) river water and preserved for storage at $4{ }^{\circ} \mathrm{C}$ with the addition of $100 \mu \mathrm{L}$ of neutralized formaldehyde to the biofilm suspension. Biofilm suspension was sonicated in an ultrasonic bath (Elmasonic $\mathrm{S} 900 \mathrm{H}$, Elma, South Orange, NJ) at $37 \mathrm{kHz}(15 \mathrm{~min})$ and vortexed (15 min) according to Buesing and Gessner (2002). For bacterial counts, $500 \mu \mathrm{L}$ aliquot of the appropriate cell suspension dilution was stained with $200 \mu \mathrm{L}$ DAPI $\left(0.01 \mathrm{mg} \mathrm{mL}^{-1}\right)$ and collected by filtration on $0.2 \mu \mathrm{m}$ pore-size black polycarbonate filters (Nuclepore, Whatman, Maidstone, UK) according to Garabetian et al. (1999). Counts were carried out on an Olympus BH2 RLFA microscope at $1250 \times$ magnification and results were expressed as cell number per $\mathrm{cm}^{2}$. Diatom density in biofilm suspension was estimated directly $\left(t_{7}\right)$ or after 5 -fold dilution $\left(t_{21}\right)$ using a Nageotte counting chamber, by counting the total number of diatoms in 30 fields ( $1.25 \mathrm{~mL}$ each, $0.5 \mathrm{~mm}$ depth), using light microscopy at $250 \times$ magnification (Olympus BH2 RLFA).

\subsubsection{Statistical analyses}

Electrochemical parameters (biofilm thickness and elasticity) were deduced by statistical adjustment using Origin 8.1 SR1 (v8.1.13 88, OriginLab Corporation, Northampton, USA). Agreement between simulated and measured thickness was evaluated by $X^{2}$ and $R^{2}$ application. The non-parametric Mann-Whitney U-test procedure was used to test for flow effects on biofilm thickness, biofilm elasticity, RDE biofilm cover, bacterial and diatom cell numbers. Correlation between biofilm architecture parameters was explored by using the Pearson $r$ coefficient. All values are given as average \pm standard deviation (SD). Statistical analyses were performed with SPSS 15.0 software for Windows, and were considered significant at $p \leq 0.05$.

\section{Results}

\subsection{Determination of biofilm thickness and elasticity}

The reciprocal steady-state current intensity $\left(\mathrm{mA}^{-1}\right)$ was plotted against the reciprocal square root of the RDE rotation speed $\left(\mathrm{rpm}^{-0.5}\right)$ in the Koutecky-Levich coordinates in the 
Fig. 2. For each EDT, before $\left(t_{0}\right)$ or after biofilm colonisation $\left(t_{7}\right.$ or $\left.t_{21}\right)$, the current increased with the RDE rotation speed according to the Levich law (Levich, 1962). For a given rotation speed, the current decreased with biofilm formation ( $t_{7} v s . t_{0}$ and $\left.t_{21} v s . t_{0}\right)$. This decrease in the current intensity measured between $t_{0}$ and $t_{7}$ or $t_{21}$ was significant and allowed thickness determination using equation (1) for $22 \mathrm{RDE}$ over 24. Connecting issues were at the origin of the defects on 2 RDE (SF7\#1 and FF21\#16). For 22 RDE (and even the most colonised ones), minimal recorded current intensities (i.e. intensity measured at the minimal rotation speed of $100 \mathrm{rpm}$ ) were higher than several tens of $\mu \mathrm{A}$ suggesting that the measurement was relevant (see Appendix). The slope is higher for 21- than for 7-day-old biofilms, and for slow than for fast flow grown biofilms (Fig. 2). Biofilm thickness measured at each RDE rotation speed $(\Omega)$ was represented on Fig. 3. The relationship between thickness and rotation speed can be analysed by considering the following law:

$\delta=\frac{1}{\left(\delta_{0}\right)^{-1}+K \Omega^{0.5}}$

$\delta_{0}(\mu \mathrm{m})$ is biofilm thickness at zero RDE rotation speed and, in other words, the theoretical biofilm thickness without any particular hydrodynamic constraint. The coefficient $K$ $\left(\mu \mathrm{m}^{-1} \mathrm{rpm}^{-1 / 2}\right)$ relates the dependence of thickness with RDE rotation speed and was used to parametise biofilm elasticity as $1 / K\left(\mu \mathrm{m} \mathrm{rpm}^{1 / 2}\right)$.
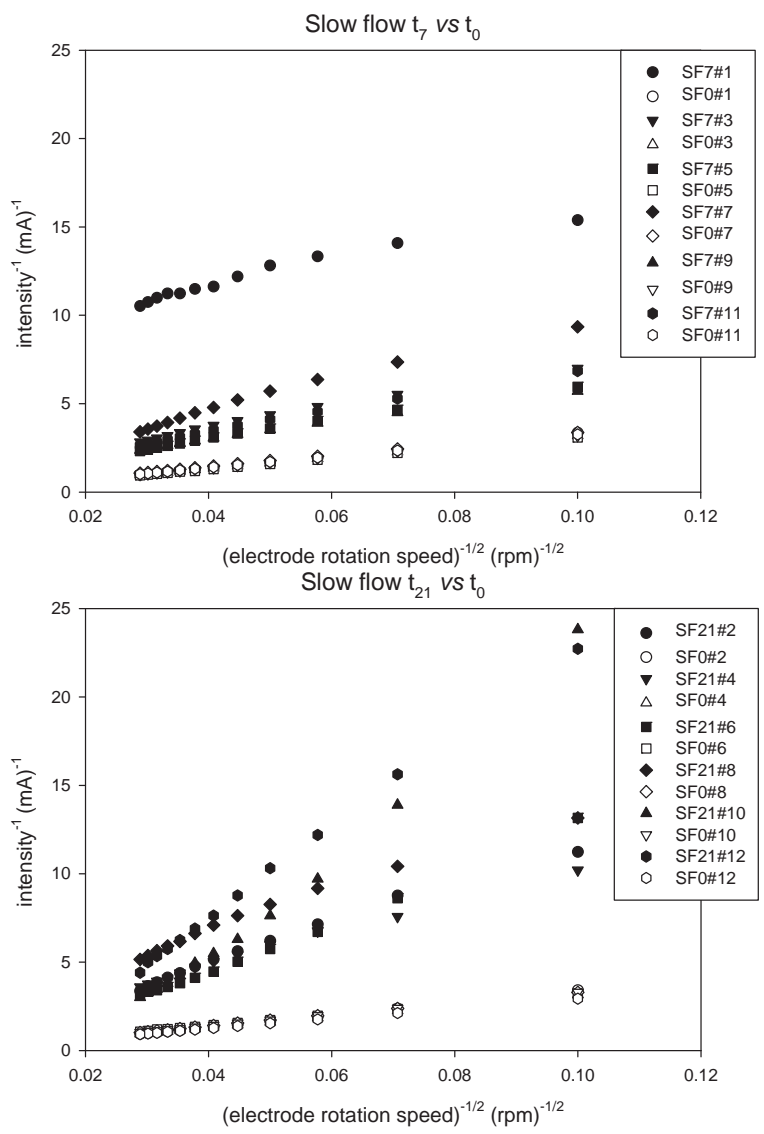

Parameter values are resumed in the Table 1 . The derivative of $\delta$ us. $\Omega$ may tend towards infinity when the rotation speed tends towards zero. This can result in a loss of accuracy on $\delta_{0}$ yielding to unrealistic too large $\delta_{0}$ for SF21\#6, SF21\#10 and SF21\#12 parameter fits (as indicated using the infinity sign in Table 1). Such unrealistic values led us to exclude the corresponding RDE results. The poor agreement between measured and simulated thicknesses at high rotation speed for these RDE is likely to suggest that the law is not applicable under high rotation speeds for thick biofilms. Nevertheless weak $\mathrm{X}^{2}$ values confirmed good fit quality for 19 out of $22 \mathrm{RDE}$; the calculated $\delta_{0}$ values are reliable and ranged from $16 \mu \mathrm{m}$ after 7 days of colonisation to $500 \mu \mathrm{m}$ after 21 days of colonisation. Electrochemically measured biofilm thicknesses were significantly correlated with stereomicroscopic estimates (Table 2). Electrochemical biofilm thickness estimates were 1.8-fold lower than stereomicroscopic estimates, ranging from 70 to $540 \mu \mathrm{m}$ (Fig. 4).

\subsection{In situ experimental settings}

The RDE supporting device was designed to be immersed into the river ensuring both in situ environmental variability (algal and bacterial inoculum, light, temperature, nutrient, etc.) and two contrasted flow conditions. Flow velocity level in the pipe was controlled by natural temporal hydraulic changes in the river. Other than days 5-6-7 when the daily mean flow peaked at $99 \mathrm{~m}^{3}$, the river experienced a period of quite stable and low

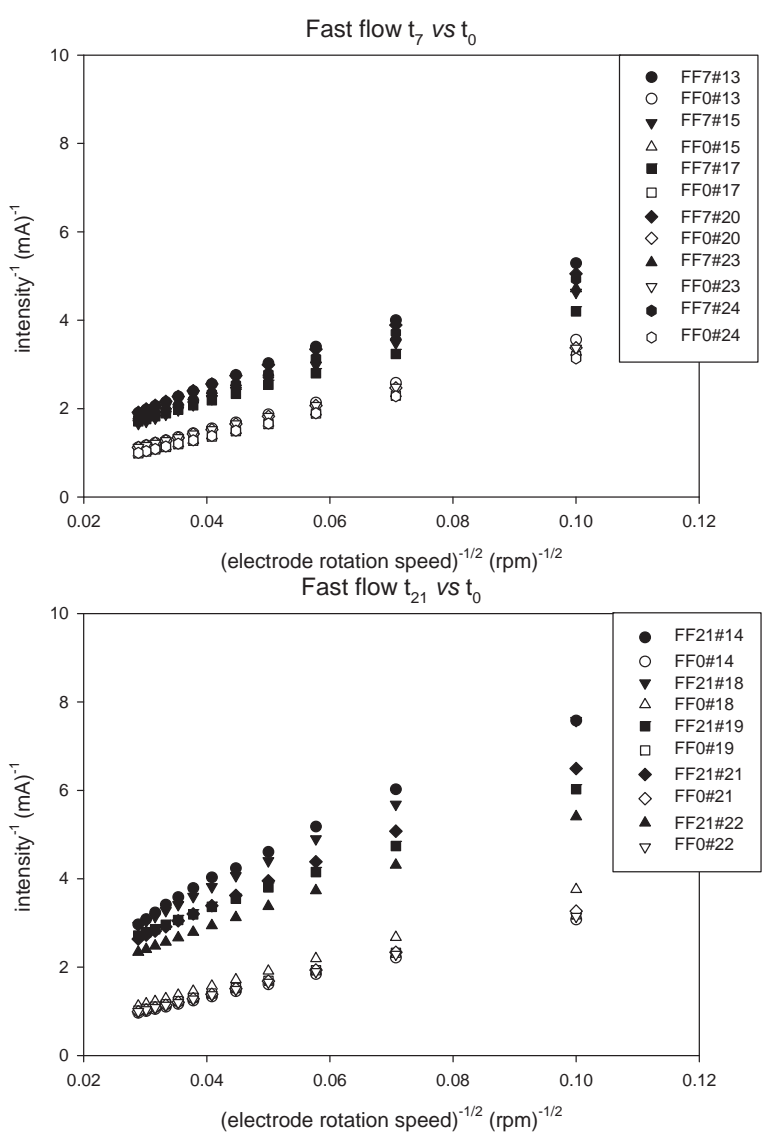

Fig. 2 - Inverse current intensity evolution with the electrode rotation speed measured on electrodes after different colonisation times ( 0 day, $t_{0}$ : closed symbols; 7 days, $t_{7}$ and 21 days, $t_{21}$ : open symbols) in two flow sections (slow flow, SF and fast flow, FF) with the ferro-/ferricyanide tracer. Each symbol corresponds to one RDE. 

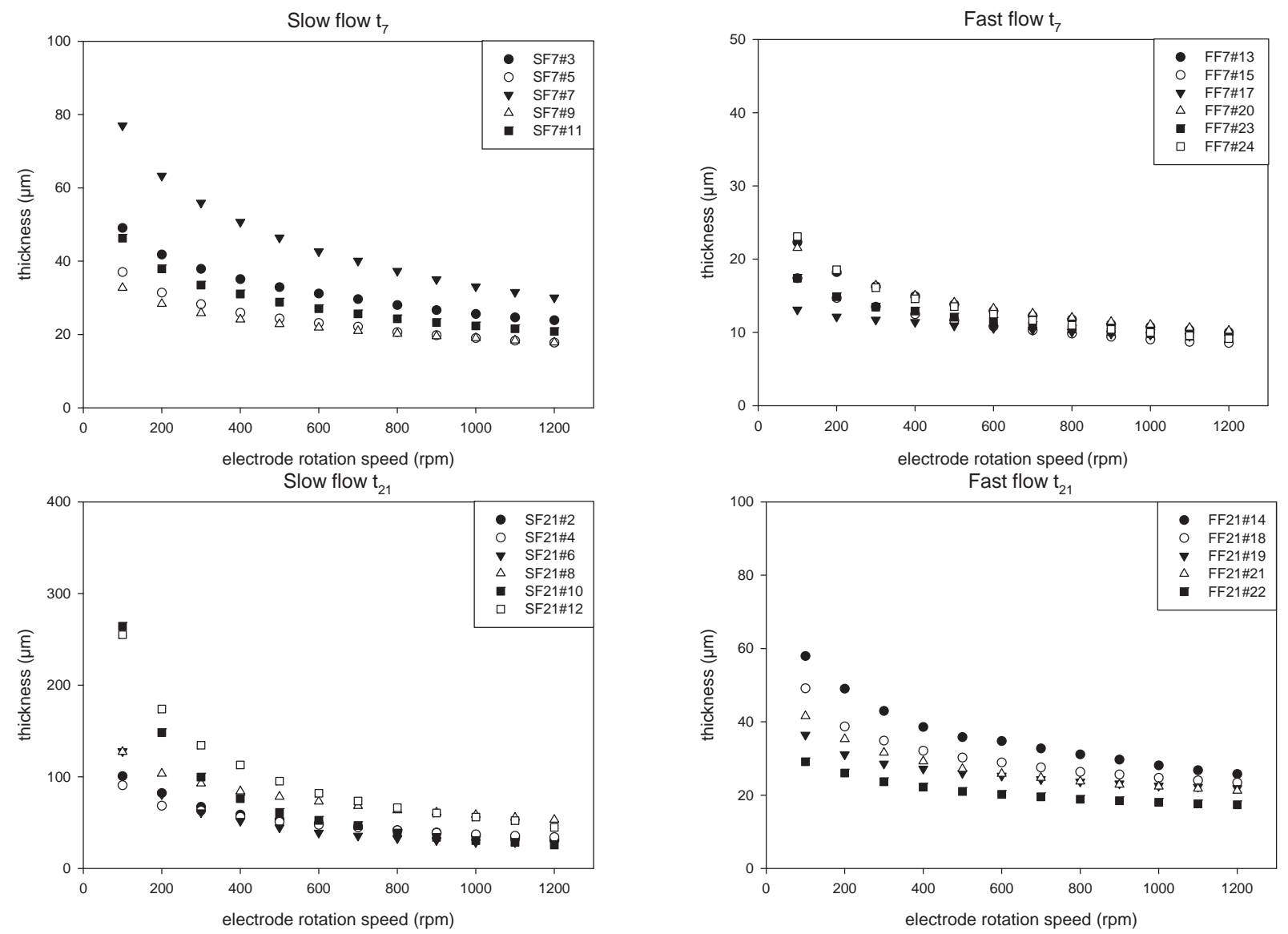

Fig. 3 - Thickness evolution with the electrode rotation speed measured on electrodes after two colonisation times $(7$ days, closed symbols and 21 days, open symbols) in two flow conditions (slow flow, SF and fast flow, FF) with the ferrocyanide tracer. Each symbol corresponds to one RDE.

flow $\left(64 \pm 10 \mathrm{~m}^{3} \mathrm{~s}^{-1}\right)$ during the experiment, favouring biofilm development (data not shown). While measurement on day 7 highlighted the above mentioned 3-day period of hydraulic disturbance, other discrete measurements on days 0 and 21 in the slow flow section (i.e. inlet of the pipe) showed quite similar flow velocity values around $0.11 \mathrm{~m} \mathrm{~s}^{-1}$ that correspond to a theoretical Reynolds number of 23,000 (Table 3). According to the device dimensions, flow velocity and Reynolds number in the fast flow section can be calculated from the former data to be around $0.46 \mathrm{~m} \mathrm{~s}^{-1}$ and 46,000 , respectively.

\subsection{Biofilm features}

Diatom accrual contributed to biofilm formation on the RDE. Diatom density increased during colonisation with $27 \times 10^{3}$ and $102 \times 10^{3}$ individuals per $\mathrm{cm}^{2}$ in the slow flow section and with $8 \times 10^{3}$ and $33 \times 10^{3}$ individuals per $\mathrm{cm}^{2}$ in the fast flow section on average at $t_{7}$ and $t_{21}$ respectively (Fig. 5a). Consistently bacterial densities increased during colonisation reaching $32 \times 10^{6}$ and $27 \times 10^{6}$ cells per $\mathrm{cm}^{2}$ on average at $t_{21}$ in the slow and fast flow sections, respectively (Fig. 5b.). Comparing the two sections, diatoms densities were significantly different, whereas bacterial densities were not. As expected, RDE biofilm cover significantly increased between $t_{7}$ and $t_{21}$ from 36 to
$59 \%$ on average in the slow flow section and from 54 to $85 \%$ on average in the fast flow section (Fig. 5c.). Stereomicroscopic thickness significantly increased between $t_{7}$ and $t_{21}$ and significantly decreased from the slow to the fast flow section (Fig. 5d).

Biofilm thickness significantly increased with time, means ranging from 100 to $340 \mu \mathrm{m}$ in slow flow and from 36 to $72 \mu \mathrm{m}$ in fast flow (Fig. 5e). Biofilm thickness was significantly affected by flow conditions at both sampling times.

Significant (or quasi significant) changes in biofilm elasticity values $(1 / K)$ occurred between $t_{7}$ and $t_{21}$ and between flow conditions (Fig. 5f.). Mean (1/K) values were significantly higher in the slow $\left(1300 \mu \mathrm{m} \mathrm{rpm}{ }^{1 / 2}\right)$ than in the fast flow section $\left(790 \mu \mathrm{m} \mathrm{rpm}^{1 / 2}\right)$ (Mann-Whitney U-test, $\left.p=0.032\right)$.

Electrochemical thickness measurements were significantly correlated with RDE biofilm cover, diatom and bacterial densities (Table 2). In addition, significant correlation was also observed between biofilm elasticity and other parameters except bacterial density.

\section{Discussion}

Ecologists agree to consider thickness increase as the driving force of biofilm structural and functional properties (Sabater 
Table 1 - Results of parameter fits (minimisation Chisquare): parameter values (average \pm square deviation) and fit quality ( $\chi^{2} /$ degree of freedom; $\mathbf{R}^{2}$ ) for each RDE.

\begin{tabular}{|c|c|c|c|c|}
\hline & $\delta_{0}(\mu \mathrm{m})$ & $K\left(\mu \mathrm{m}^{-1} \mathrm{rpm}^{-1 / 2}\right)$ & $\frac{\chi_{2}}{d o f}$ & $\mathrm{R}^{2}$ \\
\hline \multicolumn{5}{|c|}{ Slow flow $t_{7}$} \\
\hline SF7\#3 & $87 \pm 2$ & $0.00084 \pm 0.00001$ & 0.13 & 0.9978 \\
\hline SF7\#5 & $65 \pm 1$ & $0.00116 \pm 0.00001$ & 0.04 & 0.9987 \\
\hline SF7\#7 & $193 \pm 13$ & $0.00076 \pm 0.00002$ & 1.52 & 0.9926 \\
\hline SF7\#9 & $49 \pm 1$ & $0.00103 \pm 0.00001$ & 0.03 & 0.9986 \\
\hline SF7\#11 & $90 \pm 1$ & $0.00106 \pm 0.00001$ & 0.04 & 0.9993 \\
\hline \multicolumn{5}{|c|}{ Fast flow $t_{7}$} \\
\hline FF7\#13 & $44 \pm 1$ & $0.00222 \pm 0.00002$ & 0.01 & 0.9995 \\
\hline FF7\#15 & $30 \pm 1$ & $0.00241 \pm 0.00003$ & 0.02 & 0.9978 \\
\hline FF7\#17 & $16 \pm 0$ & $0.00124 \pm 0.00002$ & 0.00 & 0.9970 \\
\hline FF7\#20 & $39 \pm 0$ & $0.00203 \pm 0.00001$ & 0.01 & 0.9995 \\
\hline FF7\#23 & $27 \pm 0$ & $0.00205 \pm 0.00003$ & 0.02 & 0.9973 \\
\hline FF7\#24 & $58 \pm 1$ & $0.00260 \pm 0.00002$ & 0.02 & 0.9991 \\
\hline \multicolumn{5}{|c|}{ Slow flow $t_{21}$} \\
\hline SF21\#2 & $501 \pm 108$ & $0.00077 \pm 0.00003$ & 5.81 & 0.9869 \\
\hline SF21\#4 & $252 \pm 18$ & $0.00071 \pm 0.00002$ & 1.70 & 0.9939 \\
\hline SF21\#6 & $+\infty^{a}$ & $0.00090 \pm 0.00004$ & 58 & 0.9328 \\
\hline SF21\#8 & $277 \pm 13$ & $0.00042 \pm 0.00001$ & 1.43 & 0.9971 \\
\hline SF21\#10 & $+\infty^{a}$ & $0.00053 \pm 0.00018$ & 1222 & 0.7460 \\
\hline SF21\#12 & $+\infty^{a}$ & $0.00044 \pm 0.00002$ & 265 & 0.9304 \\
\hline \multicolumn{5}{|c|}{ Fast flow $t_{21}$} \\
\hline FF21\#14 & $114 \pm 3$ & $0.00084 \pm 0.00001$ & 0.26 & 0.9973 \\
\hline FF21\#18 & $86 \pm 4$ & $0.00094 \pm 0.00003$ & 0.78 & 0.9861 \\
\hline FF21\#19 & $48 \pm 2$ & $0.00076 \pm 0.00003$ & 0.40 & 0.9780 \\
\hline FF21\#21 & $69 \pm 1$ & $0.00097 \pm 0.00001$ & 0.09 & 0.9976 \\
\hline FF21\#22 & $40 \pm 1$ & $0.00099 \pm 0.00002$ & 0.07 & 0.9949 \\
\hline
\end{tabular}

a $+\infty$ Indicates an unrealistic too large thickness value.

and Admiraal, 2005), but, studies on river biofilms suffer from a lack of available tools to characterise biofilm architecture. The present study intended to assess the ability of an electrochemical method based on rotating disk electrode to measure and evaluate two features of biofilm architecture: thickness and elasticity.

Previously, the electrochemical method measured only very thin bacterial biofilms, between 0.9 and $3.5-\mu \mathrm{m}$ thick in tap water (Gamby et al., 2008), and up to $10-\mu \mathrm{m}$ thick in seawater (Herbert-Guillou et al., 1999). The use of $1 \mathrm{M} \mathrm{KCl}$ in the electrochemical assay could be expected to cause thickness underestimation due to EPS constriction (Frank and Belfort, 1997).

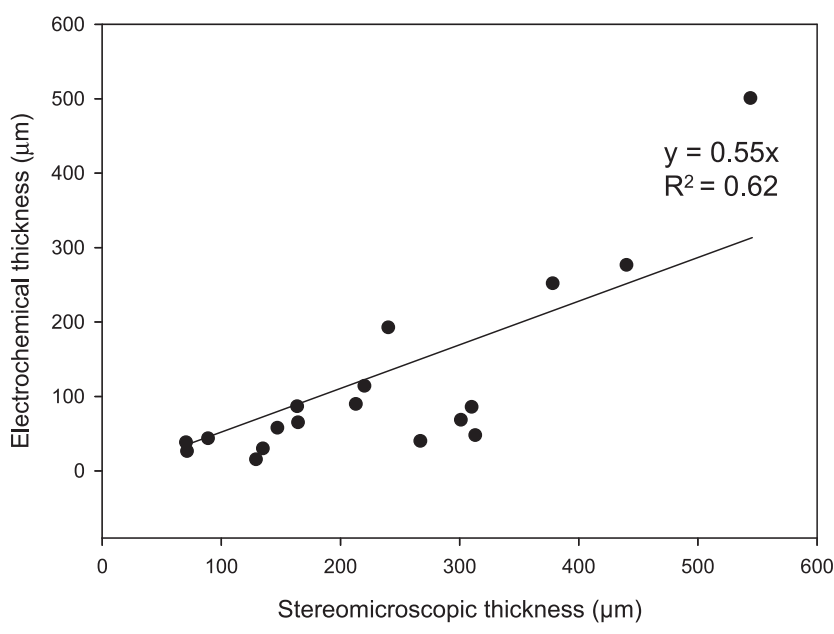

Fig. 4 - Relationship between electrochemical and stereomicroscopic measurements of biofilm thickness.

However, in their previous experiments, electrochemical estimates of biofilm thickness were validated by means of confocal laser-scanning microscopy (L'Hostis, 1996). In the present study, stereomicroscopy was used since the whole colonised RDE surface can be examined, and microbial counts can then further be done on fresh material since it does not require any previous processing such as staining, cryoembedding or cryosectioning. Stereomicroscopic measurements cannot provide absolute thickness values, but gave the upper limit of biofilm thickness range for each RDE. Nevertheless, the agreement between electrochemical measurements and stereomicroscopic estimates of biofilm thickness, 2 -fold higher than the electrochemical one, confirmed the relevance of the electrochemical approach to usefully measure thicknesses ranging from a few $\mu \mathrm{m}$ to several hundreds of $\mu \mathrm{m}$. The electrochemical method is suitable for studying biofilms containing not only prokaryotic but also eukaryotic microorganisms such as microphytobenthic algae, and particularly diatoms. Stacking of diatom cells, typically several $10 \mu \mathrm{m}$ in size, would give a biofilm cluster of hundreds of $\mu \mathrm{m}$ in thicknesses. Our measurements are thus consistent with the expected thicknesses for such biofilms.

The second parameter measurable by electrochemistry is biofilm elasticity. Initially Herbert-Guillou et al. (2000) found direct variation of bacterial biofilm thickness with electrode

Table 2 - Correlation values (Pearson $\boldsymbol{r}$ coefficient) between biofilm physiognomy parameters.

\begin{tabular}{|c|c|c|c|c|c|c|}
\hline Parameter & $\delta_{0}$ & $1 / K$ & $\begin{array}{c}\text { Bacterial } \\
\text { density }\end{array}$ & $\begin{array}{l}\text { Diatom } \\
\text { density }\end{array}$ & $\begin{array}{l}\text { RDE biofilm } \\
\text { cover }\end{array}$ & $\begin{array}{c}\text { Stereomicroscopic } \\
\text { thickness }\end{array}$ \\
\hline$\delta_{0}$ & 1.000 & $0.615^{* *}$ & $0.480^{*}$ & $0.764^{* * *}$ & $0.680^{* * *}$ & $0.833^{* * *}$ \\
\hline $1 / K$ & & 1.000 & 0.428 & $0.696^{* * *}$ & $0.700^{* * *}$ & $0.781^{* * *}$ \\
\hline Bacterial density & & & 1.000 & $0.533^{* *}$ & $0.561^{* *}$ & $0.646^{* * *}$ \\
\hline Diatom density & & & & 1.000 & $0.714^{* * *}$ & $0.755^{* * *}$ \\
\hline RDE biofilm cover & & & & & 1.000 & $0.822^{* * *}$ \\
\hline Stereomicroscopic thickness & & & & & & 1.000 \\
\hline
\end{tabular}


Table 3 - Theoretical hydraulic characteristics in the slow and fast flow sections at $t_{0}$ (first day), $t_{7}$ ( 7 colonisation days) and $t_{21}$ (21 colonisation days) estimated from measurements at the inlet of the pipe and pipe dimensions.

\begin{tabular}{lllll} 
& Parameter & \multicolumn{1}{c}{$\mathrm{t}_{0}$} & \multicolumn{1}{c}{$\mathrm{t}_{7}$} & \multicolumn{1}{c}{$\mathrm{t}_{21}$} \\
\hline Slow flow & $v\left(\mathrm{~m} \mathrm{~s}^{-1}\right)$ & 0.11 & 0.30 & 0.12 \\
& $\mathrm{Re}$ & 22,000 & 60,000 & 24,000 \\
Fast flow & $v\left(\mathrm{~m} \mathrm{~s}^{-1}\right)$ & 0.44 & 1.20 & 0.48 \\
& $\mathrm{Re}$ & 44,000 & 120,000 & 48,000 \\
\hline
\end{tabular}
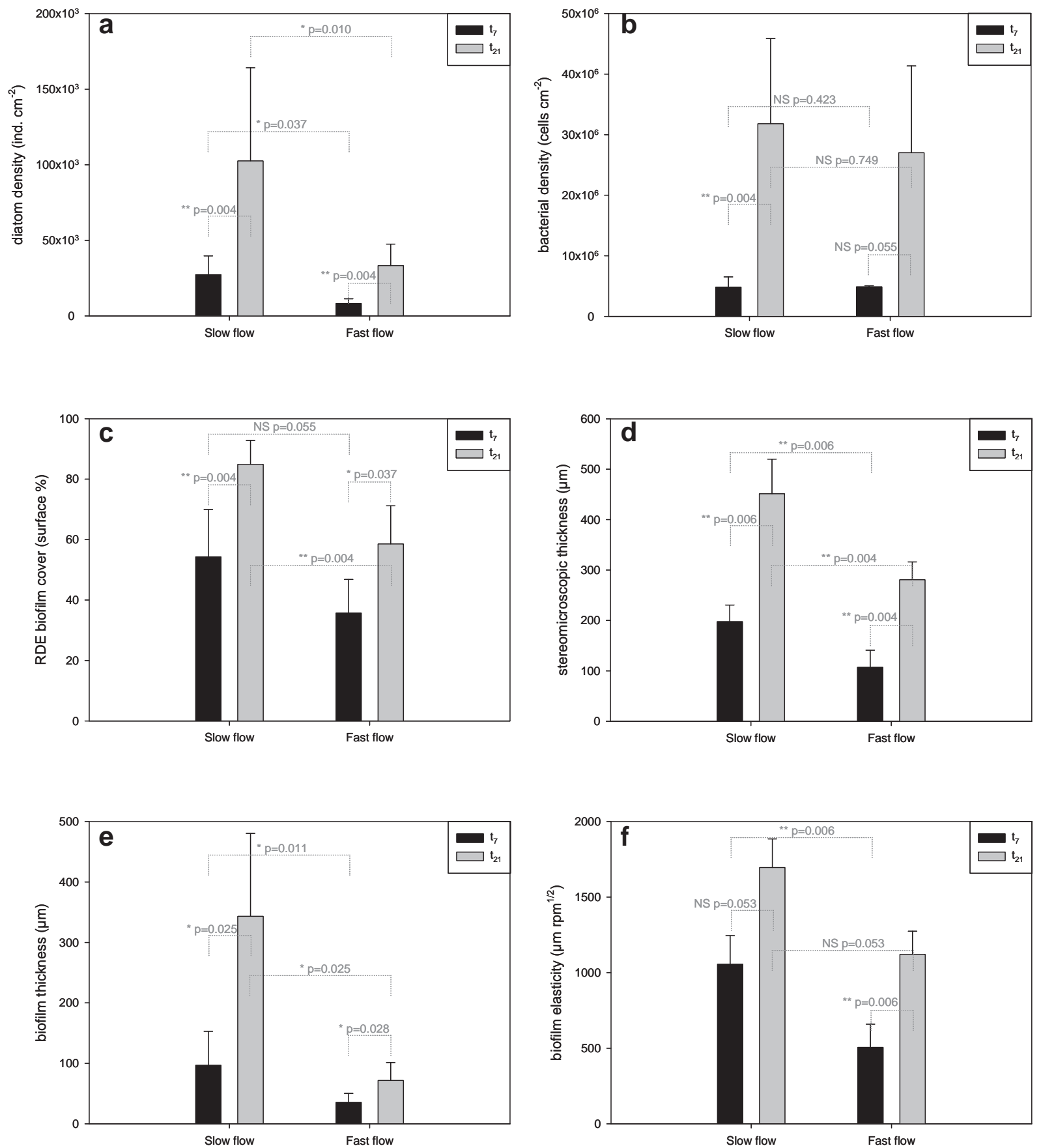

Fig. 5 - Effects of flow conditions (slow flow us. fast flow) and colonisation time ( $t_{7}$, black vertical bar vs. $t_{21}$, grey vertical bar) on diatom density (a), bacterial density (b), biofilm (electrochemical) thickness (c), elasticity (d), biofilm cover (e), and stereomicroscopic thickness (f). 
relationship between biofilm thickness and RDE rotation speed $\Omega^{-0.5}$ was proposed here. Resulting elasticity values, displaying a wide range of magnitude from about 400 to $2400 \mu \mathrm{m} \mathrm{rpm}^{1 / 2}$, express the magnitude of biofilm thickness variation due to increasing rotation speed and quantify the extent to which biofilm can be reduced by hydrodynamics constraint. The values cannot be compared to existing data, however.

The in situ experiment was designed to compare core biological parameters to electrochemical parameters on natural river biofilms. As time is one of the main drivers of biofilm structuring, biofilms were sampled at two stages of biofilm accrual pattern, colonisation and maturation. Successional changes driven by changes in benthic microalgal species strategies result in temporal changes in biofilm structure (McCormick and Stevenson, 1991; Biggs et al., 1998; Wellnitz and Brader, 2003). Successional processes were also reported for river biofilm bacterial communities (Jackson et al., 2001; Lyautey et al., 2005; Lear et al., 2008). In the studied section of the River Garonne, biofilm bacterial richness proved to increase from 0 to 7 days, and decrease from 7 to 21 days (Lyautey et al., 2005), justifying the selected sampling times. The biofilm support material is known to influence biofilm community composition (Cattaneo and Amireault, 1992) and biofilms colonising RDE platinum may have exhibited distinctive taxonomic assemblages as compared to biofilms colonising river pebbles. An in-depth comparison of biofilm structure, biomass and composition between platinum and natural substrata is still to be performed, since no data on assemblage composition was recorded in the present study. Abundances of bacteria and diatoms were monitored, showing evidence of a microbial accrual on immersed RDE surfaces. Recovered densities were comparable to those previously observed in the River Garonne biofilms for diatoms, namely $10^{5}-10^{7}$ individuals per $\mathrm{cm}^{2}$ (Eulin, 1997) and bacteria, about $10^{7}-10^{8}$ cell per $\mathrm{cm}^{2}$ (Lyautey et al., 2010). Temporal evolution of microbial densities of RDE biofilms fitted with measured thickness enhancement. Interestingly, RDE biofilm cover increased with microbial densities and thickness suggesting that phototrophic river biofilms extend both horizontally and vertically in accordance with the typical model of biofilm development from isolated column forming clusters to connected mushrooms (Costerton et al., 1987). The proposed electrochemical assay was recommended to detect and survey fouling of man-made devices in marine and drinking waters (Herbert-Guillou et al., 1999; Gamby et al., 2008). It could also be used to evaluate the early dynamics of river biofilm e.g. the kinetics in the very early stage of colonisation in time course experiments or the patchiness of early accrual zones in microscale experiments.

Another main driver of biofilm structuring is flow. The RDE supporting device was imagined on the pattern of one Venturi pipe immersed into the river ensuring both in situ environmental variability (algal and bacterial inoculum, light, temperature, nutrient, etc.) and two contrasted flow conditions. As intended, generated current velocities, 0.11 and $0.46 \mathrm{~m} \mathrm{~s}^{-1}$, were in the velocity range that favours such biofilm development (Horner and Welch, 1981). Despite disturbed hydraulic conditions for a 3-day period, stable and low daily mean flows occurred during most of the experiment especially during the whole maturation period. During stable and low-flow periods, typical Reynolds numbers (23,000 and
46,000) discriminated between optimal (Re near 22,000) and suboptimal biofilm growth conditions ( $\operatorname{Re}>40,000$; Godillot et al., 2001). Consistently, higher diatom densities and biofilm thicknesses were found in the optimal flow section as compared to the other section. To our knowledge, only one study has quantified the effect of hydrodynamics on the thickness of stream microbial biofilms (Battin et al., 2003b): thicknesses deduced from confocal laser-scanning microscopy images of cryosections of biofilm were significantly higher for biofilms cultivated on ceramic coupons in the slow flow condition $\left(0.065 \mathrm{~m} \mathrm{~s}^{-1}\right.$; $\left.\mathrm{Re}=1869\right)$ than in the fast flow condition (0.23 $\mathrm{m} \mathrm{s}^{-1}$; Re $\left.=7559\right)$. The relationship between biofilm thickness and Reynolds number in the former and in the present study were consistent with Godillot et al. (2001) showing a maximum biofilm biomass for Re about 22,000. As for biofilm elasticity in the present study, biofilms produced in the slow flow section exhibited higher elasticity values than biofilms produced in the fast flow section. Most of the microorganisms that formed river biofilm biovolume are fitted with cellular structures maintaining cellular shape (e.g. bacterial cell walls, and diatom siliceous frustules). Biofilm elasticity most probably resulted rather from intercellular space reduction than from cell size constriction. Indeed, biofilm elasticity as defined in the present study might thus refer to voids (pores and channels) within biofilm and/or the looseness of cell adhesion in biofilm. Biofilm elasticity could thus fit with the sinuosity index of Battin et al. (2003b). The multiplication of pores or voids within biofilm contributes to enlarge biofilm surface area within biofilm and therefore facilitates biofilm - water interactions and advective solute transport (De Beer et al., 1996). Such mechanical property is well studied in biofilm models used to design and evaluate performance of biofilm reactors (e.g. Picioreanu et al., 1998). Biofilm elasticity as defined in the present study could be considered as an integrative parameter of biofilm-water interaction ability, in analogy with biofilm surface enlargement in studies of bacterial biofilms of industrial environments. For example, the reduction of biofilm-water interactions forming a barrier for advective solute transport could be an adaptative response of biofilm submitted to chemical stress. Indeed communities exposed to cadmium were primarily dominated by short stalked and ad-pressed diatom species whereas control communities were dominated by filamentous diatom species (Feurtet-Mazel et al., 2003). River biofilm architecture was also affected by chronic copper exposure through the growth of the chain-forming diatom Melosira varians changing from long filaments to short tufts (Barranguet et al., 2002). Such a qualitative observation might be quantified by measuring biofilm elasticity using the proposed electrochemical method. Further studies, addressing the relationship between biofilm architecture and the proposed measure of elasticity, might then allow to test whether biofilm physiognomic properties would reflect biofilm fitness at the community scale.

\section{Conclusion}

The present study showed the suitability of an electrochemical method based on rotating disk electrode to assess 
river biofilm thickness up to $500 \mu \mathrm{m}$ thick. Results extended the application domain of the method previously developed for tap water and seawater biofilms to complex biofilms mainly constructed by algae. The method reliably detected very thin biofilms, as well as measuring biofilm thickness of several hundred- $\mu \mathrm{m}$. By analysing thickness evolution us. electrode rotation speed, the electrochemical method can be used to calculate biofilm elasticity as an estimate of the extent to which biofilm is reduced by hydrodynamic constraint. This trait of biofilm architecture would relate to biofilm-water interactions. Very few studies have been conducted on the physical properties of river biofilms, due in part to technical difficulties associated with such complex biofilms. The electrochemical method developed here combined rotating disk electrodes which can be immersed directly in the river, and an electrochemical assay requiring only a few minutes. This nondestructive method is compatible with further analyses on the same sample e.g. bacterial or algal counts, pigment, or DNA extraction and analysis. Expanding the toolbox of biofilm characterisation techniques, the rotating disk electrode electrochemical method can be used to provide novel information on river biofilm architecture.

\section{Acknowledgments}

This work stems from the project SurF "Surveillance des rivières par les biofilms" funded by CNRS PNIR "Biofilms", Région Midi-Pyrénées and Région Aquitaine (action interrégionale Aquitaine \& MidiPyrénées). The authors are grateful to H. Bouillard and C. Portier (EPOC - Station Marine d'Arcachon) for pipe manufacturing, to F. Moyse and F. Santoul for field assistance and to E. Salvo for diatom counts. The authors wish to thank Dr. E. Topp for correcting English in the ms.

\section{Appendix. Supplementary data}

Supplementary data related to this article can be found online at doi:10.1016/j.watres.2010.10.016.

\section{R E F E R E N C E S}

Anselmet, F., Ternat, F., Amielh, M., Boiron, O., Boyer, P., Pietru, L., 2009. Axial development of the mean flow in the entrance region of turbulent pipe and duct flows. Comptes Rendus Mécanique 337, 573-584.

Bakke, R., Olsson, P.Q., 1986. Biofilm thickness measurements by light microscopy. Journal of Microbial Methods 5, 93-98.

Barranguet, C., Plans, M., van der Grinten, E., Sinke, J.J., Admiraal, W., 2002. Development of photosynthetic biofilms affected by dissolved and sorbed copper in a eutrophic river. Environmental Toxicology and Chemistry 21 (9), 1955-1965.

Battin, T.J., Kaplan, L.A., Newbold, J.D., Hansen, C.M.E., 2003a. Contributions of microbial biofilms to ecosystem processes in stream ecosystems. Nature 426, 439-442.

Battin, T.J., Kaplan, L.A., Newbold, J.D., Cheng, X., Hansen, C.M.E., 2003b. Effects of current velocity on the nascent architecture of stream microbial biofilms. Applied and Environmental Microbiology 69 (9), 5443-5452.
Biggs, B.J.F., Goring, D.G., Nikora, V.I., 1998. Subsidy and stress responses of stream periphyton to gradients in water velocity as a function of community growth form. Journal of Phycology 34, 598-607.

Boulêtreau, S., Garabétian, F., Sauvage, S., Sanchez-Perez, J.-M., 2006. Assessing the importance of a self-generated detachment process in river biofilm models. Freshwater Biology 51, 901-912.

Buesing, N., Gessner, M.O., 2002. Comparison of detachment procedures for direct counts of bacteria associated with sediment particles, plant litter and epiphytic biofilms. Aquatic Microbial Ecology 27, 29-36.

Cattaneo, A., Amireault, M.C., 1992. How artificial are artificial subtrata for periphyton? Journal of the North American Benthological Society 11 (2), 244-256.

Characklis, W.G., 1990. In: Characklis, W., Marshall, K.C. (Eds.), Biofilms. Wiley, New York.

Cheng, J., Zhao, W., Liu, Y., Wu, C., Liu, C., Wang, W., 2008. Adsorption properties and gaseous mercury transformation rate of natural biofilm. Bulletin of Environmental Contamination and Toxicology 81, 516-520.

Costerton, J.W., Cheng, K.-J., Geesey, G.G., Ladd, T.I., Nickel, J.C., Dasgupta, M., Marrie, T.J., 1987. Bacterial biofilms in nature and disease. Annual Review of Microbiology 41, 435-464.

De Beer, D., Stoodley, P., Lewandowski, Z., 1996. Liquid flow and mass transport in heterogeneous biofilms. Water Research 30 (11), 2761-2765.

Deslouis, C., Tribollet, B., Viet, L., 1980. Local and overall mass transfer rates to a rotating disk in turbulent and transition flows. Electrochemica Acta 25, 1027-1032.

Dodds, W.K., Biggs, B.J.F., Lowe, R.L., 1999. Photosynthesisirradiance patterns in benthic microalgae: variations as a function of assemblage thickness and community structure. Journal of Phycology 35, 42-53.

Dorigo, U., Leboulanger, C., Berard, A., Bouchez, A., Humbert, J.-F., Montuelle, B., 2007. Lotic biofilm community structure and pesticide tolerance along a contamination gradient in a vineyard area. Aquatic Microbial Ecology 50 (1), 91-102.

Eulin, A., 1997. Les communautés de diatomées épilithiques de la Garonne, phD. Université Paul Sabatier, Toulouse, p. 248.

Feminella, J.W., Hawkins, C.P., 1995. Interactions between stream herbivores and periphyton: a quantitative analysis of past experiments. Journal of the North American Benthological Society 14 (4), 465-509.

Feurtet-Mazel, A., Gold, C., Coste, M., Boudou, A., 2003. Study of periphytic diatoms communities exposed to metallic contamination through complementary field and laboratory experiments. Journal de Physique IV 107, 467-470.

Foret, C., 2006. Maintien de la qualité des eaux dans les réseaux par des procédés innovants de traitement et de détection des biofilms. PhD, Université de Poitiers, p. 254.

Frank, B.P., Belfort, G., 1997. Intermolecular forces between extracellular polysaccharides measured using the atomic force microscope. Langmuir 13, 6234-6240.

Gamby, J., Pailleret, A., Boucher Clodic, C., Pradier, M.C., Tribollet, B., 2008. In situ detection and characterization of potable water biofilms on materials by microscopic, spectroscopic and electrochemistry methods. Electrochimica Acta 54, 66-73.

Garabetian, F., Petit, M., Lavandier, P., 1999. Does storage affect epifluorescence microscopic counts of total bacterial in freshwater samples? Comptes Rendus de l'Académie des Sciences séries III. Sciences de la Vie 322, 779-784.

Godillot, R., Caussade, B., Améziane, T., Capblancq, J., 2001. Interplay between turbulence and periphyton in rough openchannel flow. Journal of Hydraulic Research 39 (3), 227-239.

Herbert-Guillou, D., Tribollet, B., Festy, D., Kiéné, L., 1999. In situ detection and characterization of biofilm in waters by electrochemical methods. Electrochemica Acta 45, 1067-1075. 
Herbert-Guillou, D., Tribollet, B., Festy, D., 2000. Influence of the hydrodynamics on the biofilm formation by mass transport analysis. Bioelectrochemistry 53, 119-125.

Horner, R.R., Welch, E.B., 1981. Stream periphyton development in relation to current velocity and nutrients. Canadian Journal of Fisheries and Aquatic Sciences 38, 449-457.

Jackson, C.R., Churchill, P.F., Roden, E., 2001. Successional changes in bacterial assemblage structure during epilithic biofilm development. Ecology 82 (2), 555-566.

Lear, G., Anderson, M.J., Smith, J.P., Boxen, K., Lewis, G.D., 2008. Spatial and temporal heterogeneity of the bacterial communities in stream epilithic biofilms. FEMS Microbial Ecology 65, 463-473.

Levich, V.G., 1962. Physicochemical Hydrodynamics. PrenticeHall Scripta Technica, Englewood Cliffs, New Jersey.

L'Hostis, E., 1996. Détection et caractérisation de biofilms par méthodes électrochimiques. phD, Université Pierre et Marie Curie, Paris 6, p. 226.

L'Hostis, E., Compère, C., Festy, D., Tribollet, B., Deslouis, C., 1996. Characterization of biofilms on gold in natural seawater by oxygen diffusion analysis. Corrosion 43, 4-10.

Lock, M.A., 1993. In: Ford, T.E. (Ed.), Aquatic Microbiology - an Ecological Approach. Blackwell Scientific Publications, Oxford, United Kingdom, pp. 113-138.

Lyautey, E., Jackson, C.R., Cayrou, J., Rols, J.-L., Garabétian, F., 2005. Bacterial community succession in natural river biofilm assemblages. Microbial Ecology 50, 589-601.

Lyautey, E., Boulêtreau, S., Madigou, E.Y., Garabetian, F., 2010. Viability of differentiated epilithic bacterial communities in the River Garonne (SW France). Hydrobiologia 637, 207-218.

McCormick, P.V., Stevenson, R.J., 1991. Mechanisms of benthic algal succession in lotic environments. Ecology 5, 1835-1848.

Mukherjee, P.K., Chand, D.V., Chandra, J., Anderson, J.M., Ghannoum, M.A., 2008. Shear stress modulated the thickness and architecture of Candida albicans biofilms in a phasedependant manner. Mycoses 52, 440-446.

Paramonova, E., de Jong, E.D., Krom, B.P., van der Mei, H.C., Busscher, H.J., Sharma, P.K., 2007. Low-load compression testing: a novel way of measuring biofilm thickness. Applied and Environmental Microbiology 73 (21), 7023-7028.

Paul, B.J., Duthie, H.C., Taylor, W.D., 1991. Nutrient cycling by biofilms in running waters of different nutrient status. Journal of the North American Benthological Society 10, 31-41.

Peterson, C.G., 1996. In: Stevenson, R.J., Bothwell, M.L., Lowe, R.L. (Eds.), Algal Ecology: Freshwater Benthic Ecosystems. Academic Press, San Diego, pp. 375-403.

Picioreanu, C., van Loosdrecht, M.C.M., Heijnen, J.J., 1998. Mathematical modeling of biofilm structure with a hybrid differential-discrete cellular automaton approach. Biotechnology and Bioengineering 58, 101-116.

Rao, T.S., 2003. Temporal variations in an estuarine biofilm: with emphasis on nitrate reduction. Estuarine and Coastal Shelf Science $58,67-75$.

Sabater, S., Admiraal, W., 2005. In: Azim, M.E. (Ed.), Periphyton: Ecology, Exploitation and Management, pp. 159-177.

Schmid, T., Burkhard, J., Yeo, B.-S., Zhang, W., Zenobi, R., 2008. Towards chemical analysis of nanostructures in biofilms I: imaging of biological nanostructures. Analytical and Bioanalytical Chemistry 391, 1899-1905.

Sekar, R., Nair, K.V.K., Rao, V.N.R., Venugopalan, V.P., 2002. Nutrient dynamics and successional changes in a lentic freshwater biofilm. Freshwater Biology 47, 1893-1907.

Teissier, S., Torre, M., Delmas, F., Garabétian, F., 2007. Detailing biogeochemical N budgets in riverine epilithic biofilms. Journal of the North American Benthological Society 26 (2), 178-190.

Thuy Dong, T., Morin, S., Herlory, O., Feurtet-Mazel, A., Coste, M., Boudou, A., 2008. Seasonal effects of cadmium accumulation in periphytic diatom communities of freshwater biofilms. Aquatic Toxicology 90, 19-28.

Wellnitz, T., Brader, R.B., 2003. Mechanisms influencing community composition and succession in mountain stream periphyton: interactions between scouring history, grazing, and irradiance. Journal of the North American Benthological Society $22(4), 528-541$.

Wetzel, R.G., 1975. In: Whitton, B.A. (Ed.), River Ecology. Blackwell Sci. Publ., Oxford. 